\title{
AN ANALYSIS OF CIRCADIAN RHYTHMICITY OF HEART RATE IN TETRAPLEGIC HUMAN SUBJECTS
}

\author{
By John E. Christ, M.D., Ph.D. \\ Instructor in Physiology and Resident in Plastic Surgery, Baylor College of Medicine, Texas \\ Medical Center, Houston, Texas 77030, U.S.A.
}

\begin{abstract}
Eight tetraplegic human volunteer subjects from the Veterans Administration Hospital in Houston, Texas, had their heart rates monitored at half-hour intervals for 24 hours. Autocovariance analysis demonstrated circadian rhythms of heart rate in four chronic tetraplegic subjects and one acute tetraplegic subject. The remaining three subacute tetraplegic subjects demonstrated no circadian rhythmicity of heart rate. It is postulated that central denervation of the heart from the sympathetic division of the autonomic nervous system in cervical cord injury results in loss of circadian rhythmicity in heart rate until the vagus of the parasympathetic division obtains control, sympathetic spinal cord centres re-establish control, or an orderly interaction of both occurs. Further study appears indicated.
\end{abstract}

\section{Introduction}

NORMAL human subjects have demonstrated significantly daily biological rhythms in every system studied (Aschoff, 1965). In tetraplegic human subjects however, it appears that a single circadian study of fluid and electrolyte balance has been done demonstrating significant rhythms only in potassium excretion and fluid balance. No study has been done showing circadian rhythmicity of heart rate in the tetraplegic human. This study was therefore undertaken in an attempt to observe the circadian rhythmicity of heart rate in tetraplegic human subjects.

\section{Methods and Materials}

Eight tetraplegic human patients were selected and invited to volunteer for this study from the Spinal Cord Injury Section of the Veterans Administration Hospital in Houston, Texas. All subjects (average age 37.5 years) had sustained cervical cord injury between levels $\mathrm{C}_{4}$ and $\mathrm{C}_{7}$. The injury in one subject was acute (injury less than 2 months), three were subacute (injury between 2 and Io months), and four were chronic (injury more than Io months). No restrictions were placed on activity so as not to interfere with the routine regimen of therapy; five remained at complete bed rest, three were mobile in wheelchairs at intervals. The monitoring period began I March 1974; pulses by palpation were taken at half-hour intervals from 21.30 to 09.30, 2 March 1974. All data was compiled, plotted, and subjected to autocovariance analysis.

\section{Observations}

During the 24-hour monitoring period the individual mean pulse rate varied between 58 beats per minute and 106 beats per minute. A low of 44 beats per minute 
was recorded in one subject, a high of 124 beats per minute in another. The rates appear independent of length of injury. Table I summarizes the 24-hour data.

Plots of pulse rate (Fig. I-8) show marked variations in rate during each half-hour period. However, night rates tend to be lower than day rates. Pulse rates also appear to be lowest in the early morning as in normal subjects. Activity accompanied by change in position resulted in an increase in heart rate.

\section{TABLE I}

Compilation of tetraplegic volunteer subject data in 24 -hour study of pulse rate

\begin{tabular}{|c|c|c|c|c|c|c|c|c|}
\hline Subject & $\begin{array}{l}\text { Age at } \\
\text { study }\end{array}$ & $\begin{array}{l}\text { Level of } \\
\text { injury }\end{array}$ & $\begin{array}{l}\text { Date of } \\
\text { injury } \\
\text { (Class) }\end{array}$ & $\begin{array}{l}\text { Min. } \\
\text { rate* }\end{array}$ & $\begin{array}{l}\text { Max. } \\
\text { rate* }\end{array}$ & Mean* & $\begin{array}{l}\text { Std. } \\
\text { dev.* }\end{array}$ & $\begin{array}{c}\text { Calculated } \\
\text { autocovariance } \\
\text { period }\end{array}$ \\
\hline I & $26 \mathrm{yrs}$ & C6 & $\begin{array}{c}\text { I8-I2-73 } \\
\text { (acute) }\end{array}$ & 80 & I 24 & 96 & $10 \cdot 8$ & $23.5 \mathrm{hrs}$ \\
\hline 2 & $25 \mathrm{yrs}$ & $\mathrm{C}_{4}$ & $\begin{array}{c}6-8-73 \\
\text { (subacute) }\end{array}$ & 48 & IIO & 76 & $13 \cdot 2$ & I $5.5 \mathrm{hrs}$ \\
\hline 3 & $6 \mathrm{r} \mathrm{yrs}$ & $\mathrm{C}_{4}$ & $\begin{array}{c}24-7-73 \\
\text { (subacute) }\end{array}$ & 58 & 86 & 69 & $7 \cdot 9$ & $20 \cdot 0 \mathrm{hrs}$ \\
\hline 4 & $47 \mathrm{yrs}$ & C6 & $\begin{array}{c}29-6-73 \\
\text { (subacute) }\end{array}$ & 60 & 100 & 77 & $10 \cdot 2$ & $20.5 \mathrm{hrs}$ \\
\hline 5 & I9 yrs & $\mathrm{C}_{4}$ & $\begin{array}{l}23-\mathrm{I}-73 \\
\text { (chronic) }\end{array}$ & 60 & 108 & 84 & $9 \cdot 9$ & $23.5 \mathrm{hrs}$ \\
\hline 6 & $47 \mathrm{yrs}$ & C6 & $\begin{array}{l}23-12-72 \\
\text { (chronic) }\end{array}$ & 44 & 68 & 58 & $5 \cdot 3$ & $23 \cdot 0 \mathrm{hrs}$ \\
\hline 7 & $29 \mathrm{yrs}$ & $\mathrm{C}_{7}$ & $\begin{array}{l}\text { I5- 7-67 } \\
\text { (chronic) }\end{array}$ & 88 & 120 & I06 & $8 \cdot 0$ & $24.0 \mathrm{hrs}$ \\
\hline 8 & $46 \mathrm{yrs}$ & $\mathrm{C}_{7}$ & $\begin{array}{r}\text { 5-I I-64 } \\
\text { (chronic) }\end{array}$ & 60 & 120 & 96 & 15.0 & $23.5 \mathrm{hrs}$ \\
\hline
\end{tabular}

* Beats/minute.

Autocovariance analysis, that is, examination of a periodic event filtered from background noise (Blackman and Tukey, 1958), revealed an exact 24-hour period in only one subject (Fig. I). Three subjects had 23.5-hour periods (Figs 2, 3 and 4 ) and one other a 23-hour period (Fig. 5). These results may be considered well within the limits of experimental error. Of the remaining three subjects, one demonstrated a $20 \cdot 5$-hour period (Fig. 6), one a 20 hour period (Fig. 7), and the last subject a I5.5-hour period (Fig. 8). There appears to be no relation between the level of injury and the periodicity of the heart rate. It is interesting to note that the absence of a circadian rhythm of heart rate appears in the three subjects which are in the subacute group. Longer periods of monitoring are necessary before formulating more than tenative conclusions on this data. 


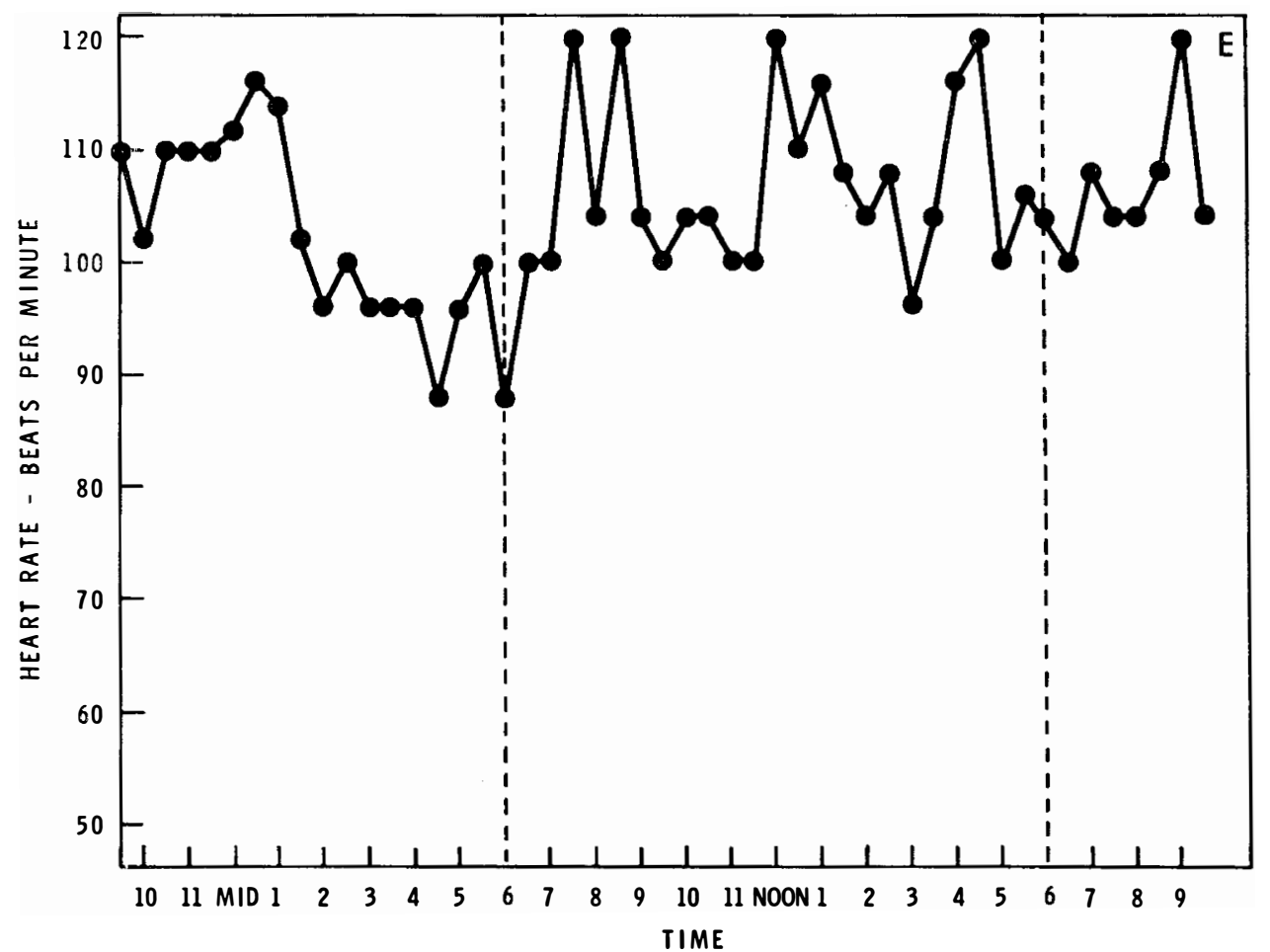

FIG. I-Subject 7 with chronic $\mathrm{C}_{7}$ injury. Lowest rates are seen during the night, the highest during the day. Autocovariance analysis confirms a periodicity of 24 hours. (Letters in right upper corner refer to subject initial.)

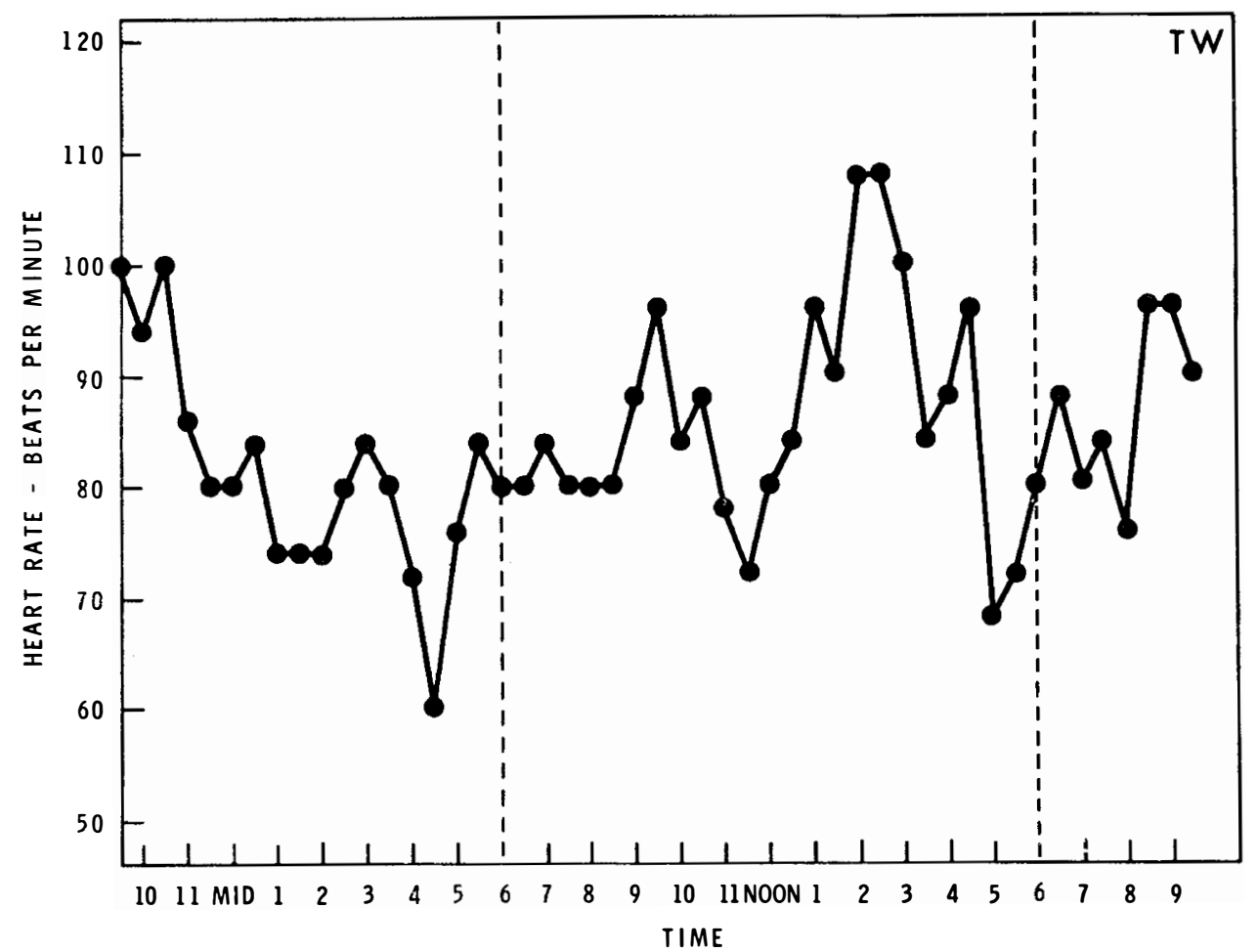

Fig. 2-Subject 5 with chronic $\mathrm{C}_{4}$ injury. A rhythm suggesting a sinusoidal pattern may be seen in this subject. Night rates are lower than day rates. Autocovariance analysis shows a 23.5-hour period. 


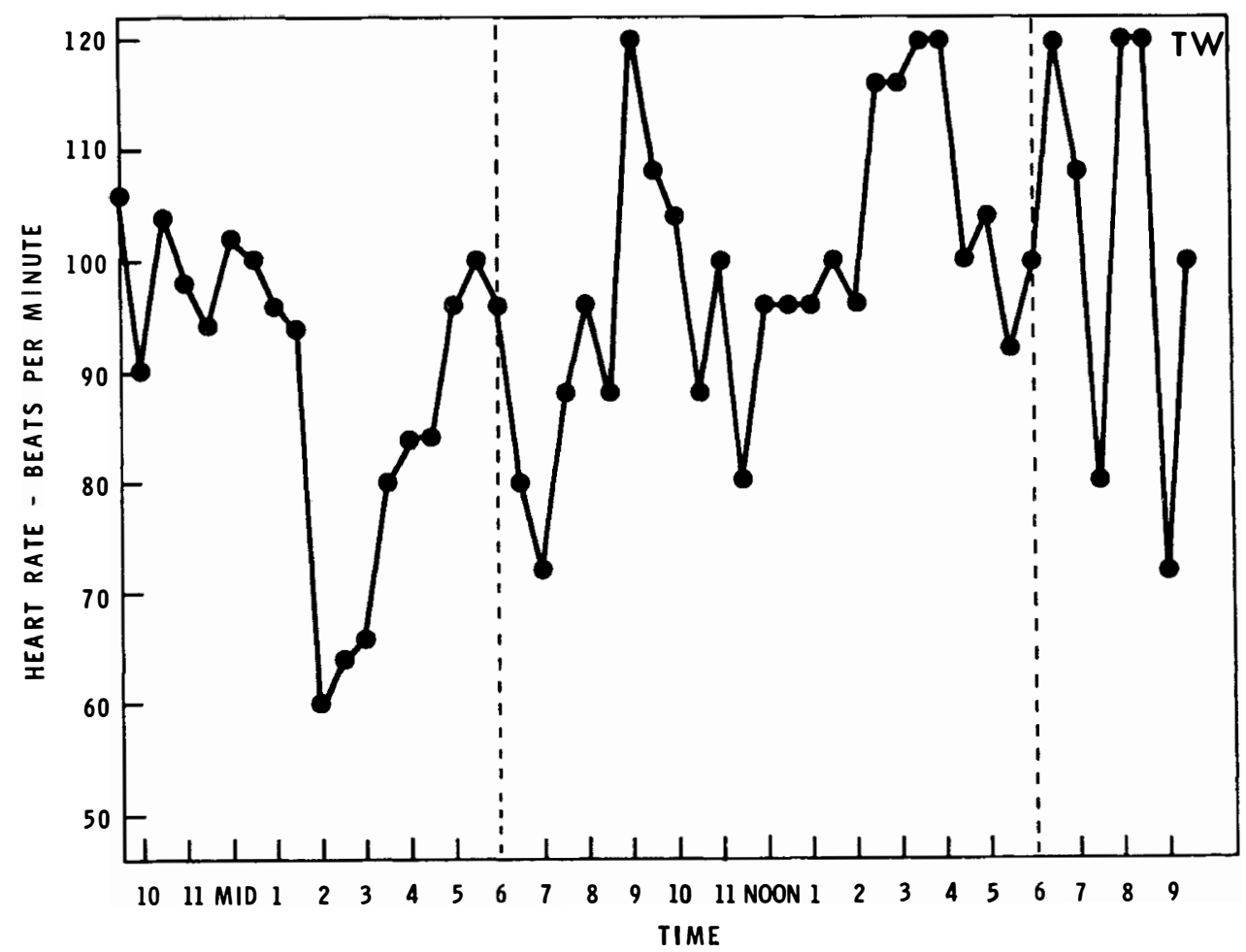

FIG. 3-Subject 8 with chronic $\mathrm{C}_{7}$ injury. Lowest rates are seen during the night, highest during the day. Autocovariance analysis shows a $23 \cdot 5$-hour period.

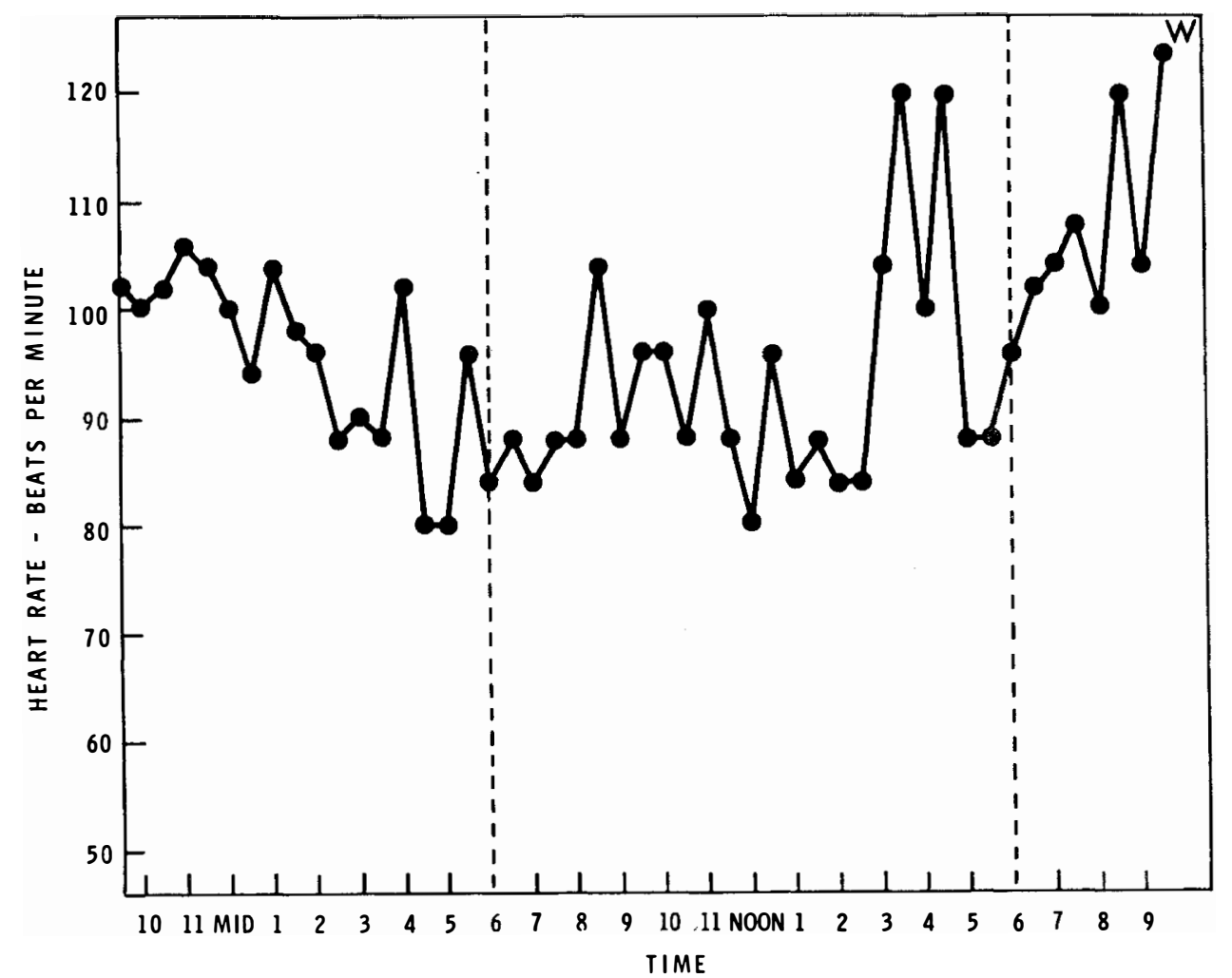

FIG. 4-Subject I with acute C6 injury. Lowest rates are seen at night, highest in the afternoon and evening. Autocovariance analysis shows a 23.5-hour period. 


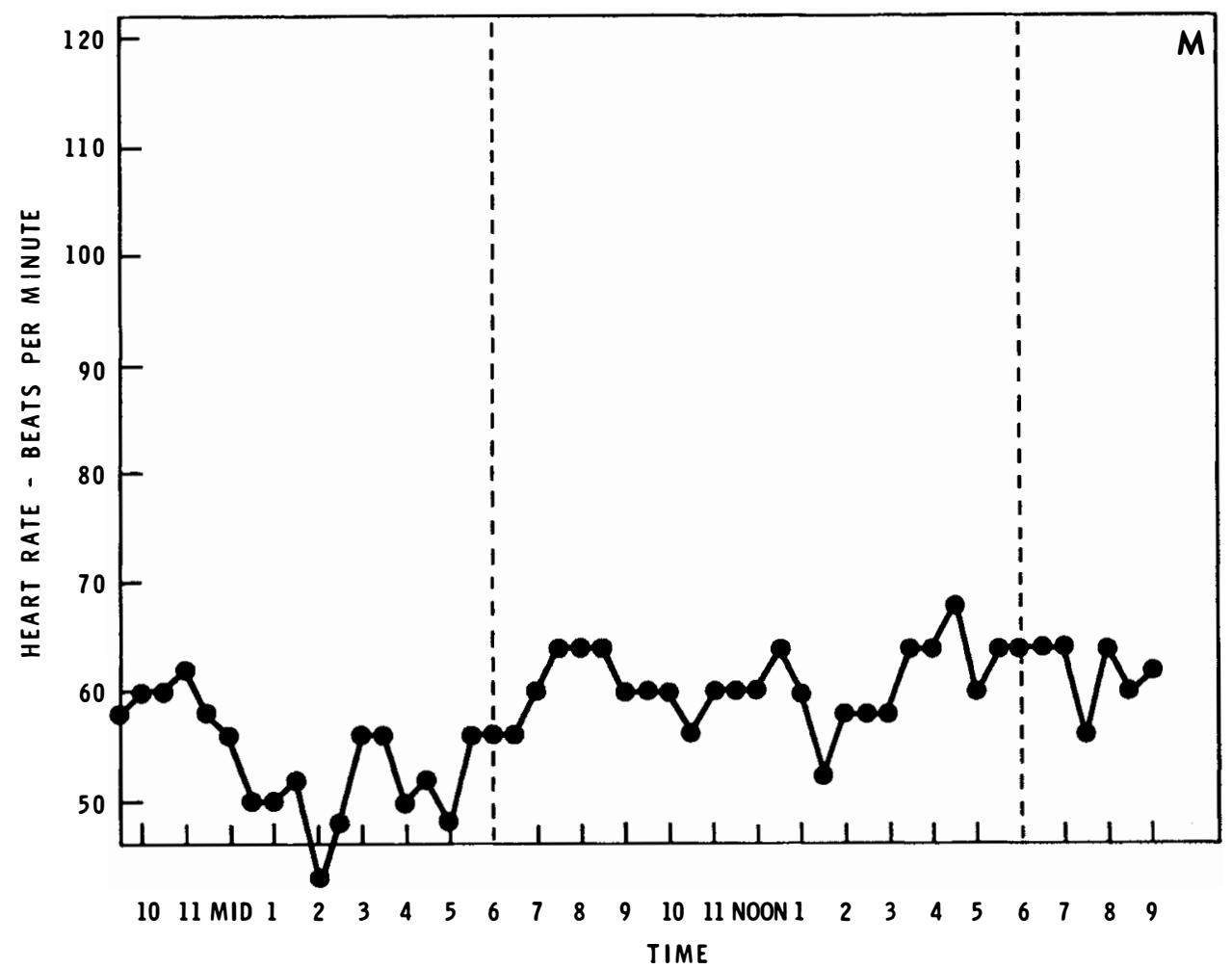

FIG. 5-Subject 6 with chronic C6 injury. The subject had the lowest average rate ( 58 beats per minute) suggesting complete vagal regulations. Lowest rates are seen during the night, highest during the day. Autocovariance analysis shows a 23-hour period.

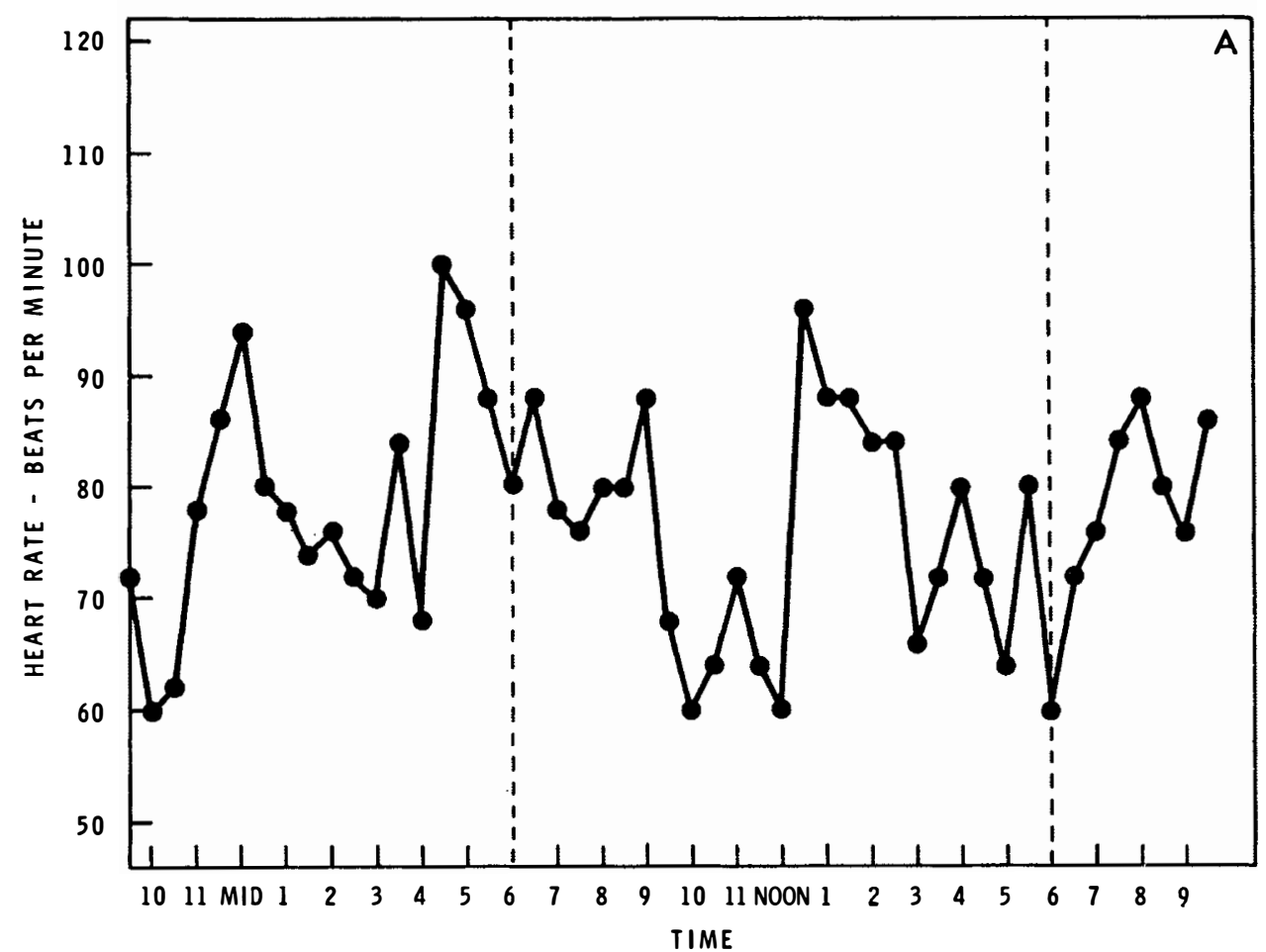

FIG. 6-Subject 4 with subacute C6 injury. Description of this plot is difficult, however autocovariance analysis shows an abnormal period of 20.5 hours. 


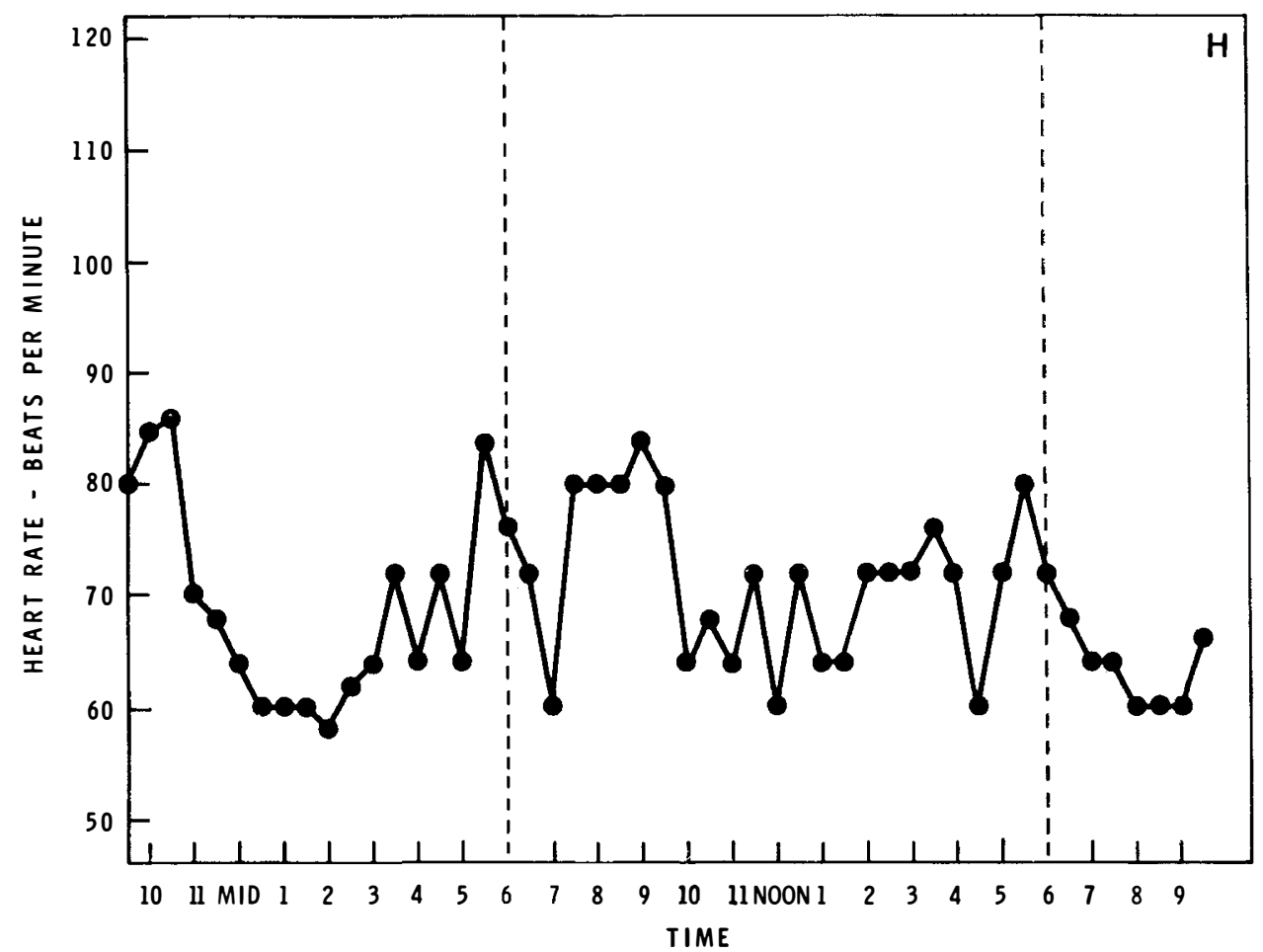

FIG. 7-Subject 3 with subacute $\mathrm{C}_{4}$ injury. Lowest rates are seen during the night, highest during the day. Autocovariance analysis shows a 20-hour period.

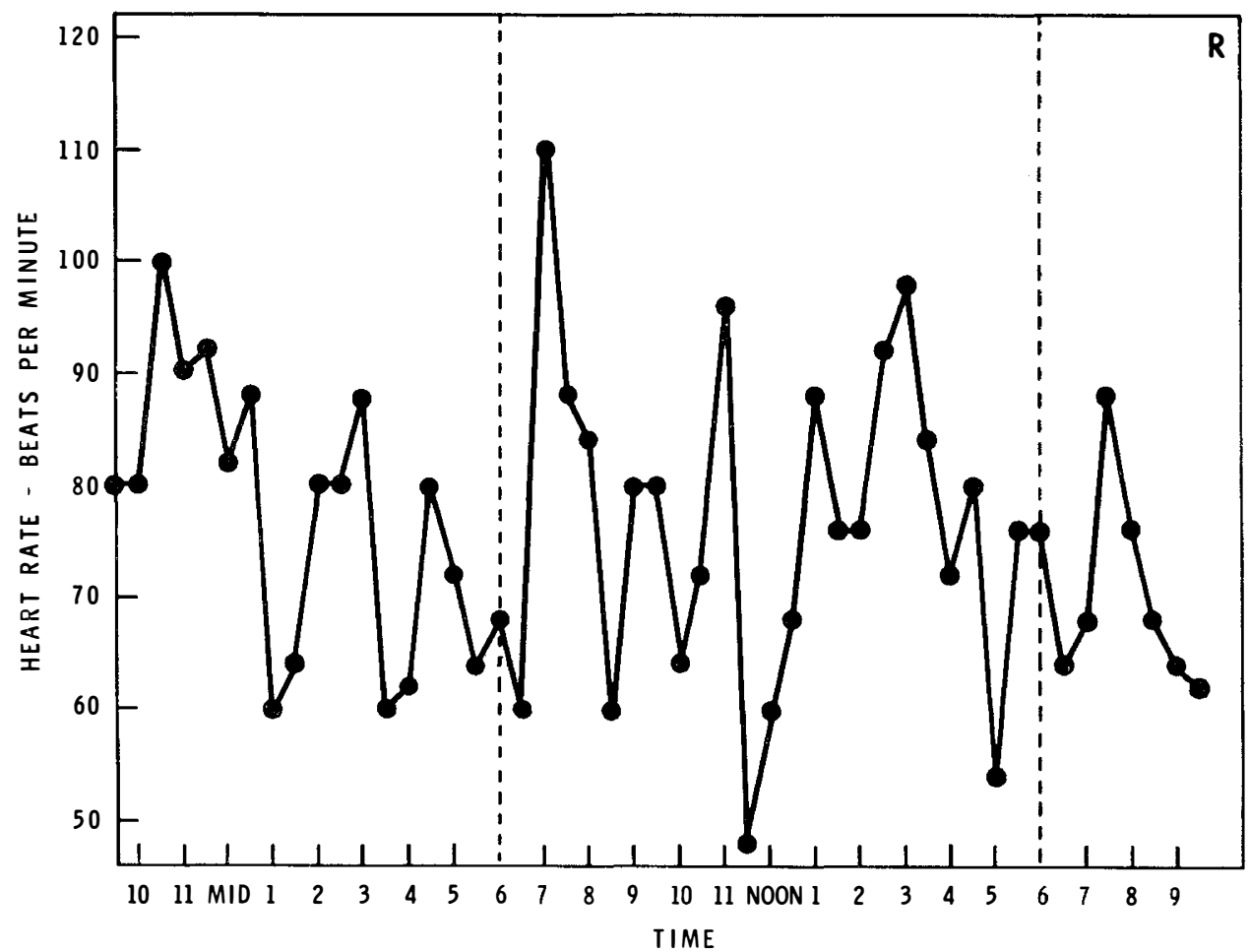

FIg. 8-Subject 2 with subacute $\mathrm{C}_{4}$ injury. The two lowest rates are seen at II.30 a.m. and 5 p.m.; the two highest rates occur at I0.30 p.m. and 7 a.m. There is marked change in heart rate every 60 to 90 minutes. Autocovariance analysis shows a $15 \cdot 5$-hour period. 


\section{Discussion}

Cervical spinal cord injury, in addition to interrupting most, if not all, neural pathways for all sensory modalities and voluntary motor functions below the site of injury, also affects efferent discharge from the autonomic nervous system. Although total cervical spinal cord destruction separates the heart from the central action of the sympathetic division of the autonomic nervous system, reflex action is still possible, since the parasympathetic division which reaches the heart via the vagus remains intact. In decapitate dogs minute to minute rhythmic changes in blood pressure and heart rate has been observed and related to rhythmic changes in activity from spinal sympathetic vasomotor centres (Peters et al., 1969). In I972 Greenheart and Mauck (1976) demonstrated immediate changes in cardiac rhythm and conduction in experimentally induced acute cervical cord injury in dogs. No comparable study of this sort has been done in man.

The heart in tetraplegia is essentially denervated from the central control of the sympathetic division of the autonomic nervous system, however the parasympathetic division remains intact. Assuming that the acute tetraplegic subject in this series may have had intact sympathetic pathways, acute and subacute tetraplegic humans appear to have disordered heart rate circadian rhythms based on autonomic pathway interruption. With time (a period yet to be specified) either intact vagal parasympathetic pathways accommodate to the lack of sympathetic tone or sympathetic centres in the cord themselves begin to function rhythmically to re-establish circadian rhythmicity of the heart beat. An alternate explanation may explain the observed data if circadian rhythmicity of heart rate is seen as a completely vagal phenomenon, disorder of its control may occur from disordered and excessive sympathetic cord activity after spinal cord injury. The apparent circadian rhythm seen in the acute subject here may represent a period of spinal shock prior to excessive sympathetic discharge.

\section{Conclusions}

This study demonstrates a circadian periodicity of heart rate in four chronic tetraplegic human subjects. The nature of this rhythm may be considered independent of direct central innervation from the sympathetic division of the autonomic nervous system. Of the three subacute tetraplegic human subjects the lack of circadian periodicity may be a direct result of the lack of establishment of vagal dominance over sympathetic cord centres. Clearly the elucidation of the nature of the circadian rhythm of heart rate in tetraplegic humans merits further investigation.

\section{RÉSUMÉ}

Le pouls cardiaque a été enregistré, à un interval d'une demi-heure, pendant 24 heures, dans huit sujets tétraplégiques volontaires. L'analyse autocovariance a demontré le rythme circadien du pouls cardiaque dans quatre sujets avec tétraplégie chronique et dans un sujet avec tétraplégie aiguë. Les trois autres sujets avec tétraplégie subaiguë n'ont démontré aucun rythme circadian cardiaque. Il a été postulé que la dénnervation sympatique centrale du coeur dans le cas de lacération du cordon médullaire résulte dans la perte du rythme circadien du pouls cardiaque, jusqu'à ce que le nerf vague parasympatique obtient le contrôle, ou jusqu'à ce que les centres sympatiques de la moëlle épinière le rétablissent, ou bien lorsq'une interaction de ces deux systèmes se réalise. D'autres études apparaissent nécessaires. 


\section{ZUSAMMENFASSUNG}

An acht freiwilligen Tetraplegikern wurde der Herzrhythmus alle dreissig Minuten während vierundzwanzig Stunden aufgezeichnet. Autokovarianzanalyse zeigten zirkadischen Herzrhythmus in vier chronischen Tetraplegikern und in einem akuten. Die Übungen drei Tetraplegiker zeigte keinen solchen zirkadischen Rhythmus. Es wird angenommen, dass die wegen Rückenmarksverletzungen entstehende Zentraldenervation des Herzens vom sympatischen Nervenzystem einen Verlust des zirkadischen Herzrhythmus erzeugt. Dieser Verlust bleibt, bis entweder der Nervus Vagus (parasympatisch), oder die sympatische Rückenmarkszentren die Kontrolle wiederherstellen, oder es zur geordnetem Interaktion von beiden kommt. Weitere Untersuchungen sind nötig.

\section{REFERENCES}

Aschoff, J. (1960). Exogenous and endogenous components in circadian ryhthms. Cold Spring Harbor Symposium on Quantitative Biology, 25, $\mathrm{I}$.

Aschoff, J. (1965). Circadian rhythms in man. Science, 148, 1427.

Blackman, R. B. \& Tukey, J. W. (1958). The measurement of Power Spectra. Dover Publications, Inc., New York.

Claus-Walker, J., Campos, R. J., Carter, R. E., Lipscomb, H. S. \& Valbona, C. (I972). Longitudinal analysis of daily excretory rhythms in men with tetraplegia due to cervical cord transections. Paraplegia, 10, I42.

GreEnHART, J. H. \& MAUCK, H. P. (I972). The effect of cervical cord injury on cardiac rhythm and conduction. Amer. Heart f., 83, 659.

Peters, J. L., Geddes, L. A. \& Moore, A. G. (I969). Rhythmic fluctuations in blood pressure in the decapitate dog. Cardiovasc. Res. Ctr. Bull., 7(3), I I I. 